\title{
Norske pasienter for tungt sedert
}

\section{Norske intensivavdelinger har en uorganisert praksis for vurdering av smerte, ubehag og forvirring hos kritisk syke pasienter. Mange av pasientene blir dermed for tungt sedert.}

Sykepleier Hilde Wøien har kartlagt smertelindring og sedasjonspraksis ved 54 norske intensivavdelinger og studert hva som legges til grunn når smerter, ubehag og forvirring skal vurderes og behandles. Legene og sykepleierne beskrev praksisen som uorganisert og usystematisk.

- Intensivpersonell brukte ikke anbefalte vurderingsverktøy og hadde heller ingen andre faste rutiner for å vurdere pasientens smertetilstand, sedasjonsnivå og grad av forvirring. Dette er dårlig, sett i internasjonal sammenheng. De ansatte rapporterte også en uro for bivirkninger ved bruk av analgetika og sedativer, sier Wøien.

På bakgrunn av resultatene fra den nasjonale kartleggingen implementerte hun i 2009 internasjonalt godkjente metoder for vurdering av smerte, sedasjon og forvirring ved to intensivavdelinger. Trent helsepersonell tok metodene i bruk, og 139 pasienter inngikk i en studie. Wøien fant at forekomsten av delirium blant intensivpasientene kun var $23 \%$. Noe av årsaken kan være overse- dasjon. $30 \%$ av pasientene var dypt sedert under hele intensivoppholdet, et tall som er svært høyt i internasjonal sammenheng. Vurderingsverktøyene ga imidlertid stor forbedring i dokumentasjon og målrettet arbeid, og ble oppfattet som et hjelpemiddel som ga økt kontroll og bedre tverrfaglig samarbeid, selv om personalet aldri ville legge til side sin egen bedømmingsevne.

- I den grad pasienten tåler det, bør han få være våken under intensivbehandlingen. Da er risikoen for komplikasjoner lavere. Våkne pasienter kan selv kommunisere smerte og ubehag, og forvirringstilstander kan lettere oppdages, sier Wøien.

Hun understreker også viktigheten av kompetanse, erfaring og tverrfaglig samarbeid og mener intensivavdelingene blant annet trenger et fast team av anestesileger.

\section{Eline Feiring}

eline.feiring@legeforeningen.no

Tidsskriftet

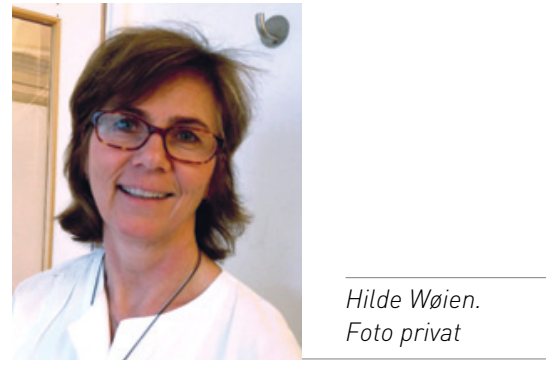

Disputas

Hilde Wøien disputerte for ph.d.-graden ved Universitetet i Oslo 6.5. 2013 med avhandlingen The significance of a systematic approach in intensive care pain treatment and sedation.

\section{Symptomprofiler ved psykiske lidelser}

\author{
Ti års oppfølging etter første fase av psykose gir kunnskap om hvordan \\ hallusinasjoner, apati og flat affekt påvirker suicidalitet, livskvalitet \\ og sosial funksjon.
}

Psykotiske lidelser utvikles gjennom flere episoder. Førstegangspsykose (first episode psychosis, FEP) er episoden hvor symptomene har utviklet seg til et visst nivå for så å holde seg der. - Studier som følger opp pasienter helt fra denne episoden, kan lære oss mye om hvordan symptomene utvikler seg over tid, sier Julie Horgen Evensen.

Hun har studert symptomutvikling og symptomprofiler hos pasienter fra TIPS-studien (Tidlig oppdagelse og behandling av psykose). Materialet omfatter 301 pasienter med førstegangspsykose som ble intervjuet ved sykdomsstart, etter tre måneder og etter ett, to, fem og ti år. - Vi har identifisert pasienter med vrangforestillinger som eneste symptom og pasienter med hallusinasjoner som eneste symptom. Den viktigste forskjellen mellom de to gruppene var at pasientgruppen med hallusinasjoner skåret betydelig høyere på suicidalitet og hadde betydelig høyere selvmordsrate. Denne gruppen hadde også bedre sykdomsinnsikt, noe som kan bidra til å forklare den høye graden av suicidalitet.

- Vi undersøkte også klinisk relevant apati hos pasientene ti år etter sykdomsdebut, og fant at dette gjaldt $30 \%$ av pasientene i studien. Klinisk apati var sterkt knyttet til dårlig generell funksjon og dårlig livskvalitet, sier Evensen.

Hun har også identifisert pasienter med ulik symptomutvikling av flat affekt, bl.a. manglende endring $i$ ansiktsuttrykk og manglende respons. Dette symptomet var mindre stabilt enn det som er vist tidligere, og det var vedvarende hos bare $5 \%$ av pasientene. Flat affekt var knyttet til dårligere sosial funksjon både før sykdomsdebut og gjennom hele oppfølgingsperioden.

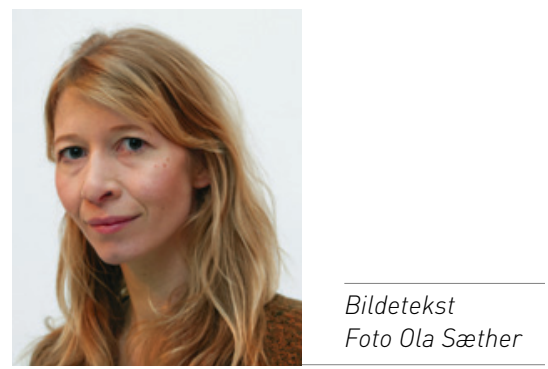

Disputas

Julie Horgen Evensen disputerte for ph.dgraden ved Universitetet i Oslo 4.2. 2013 med avhandlingen Symptom profiles in first episode psychosis. A ten year follow-up study. 